Floodplain/Wetlands Assessment for the Remediation of Vicinity Property 9 at the Weldon Spring Site, Weldon Spring, Missouri

Environmental Assessment Division Argonne National Laboratory

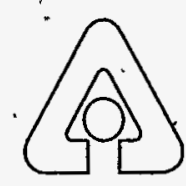

- Operated by The University of Chicago, under Contract W-31-109-Eng-38, for the

United States Department of Energy 


\section{Argonne National Laboratory}

Argonne National Laboratory, with facilities in the states of llinois and Idaho, is owned by the United States Government, and operated by the University of Chicago under the provisions of a contract with the Department of Energy.

This technical report is a product of Argonne's Environmental Assessment Division. For information on the division's scientific and engineering activities, contact:

Director; Environmental Assessment Division

Argonne National Laboratory

Argonne; Illinois 60439-4815

Telephone (708) 252-3107

Publishing support seivices were provided by Argonne's Information and Publishing Division (for more information, see IPD's home page: http://www.ipd.anl.gov/).

\section{Disclaimer}

This report was prepared as an account of work sponsored by an ágency of the United States Govemment. Neither the United States Government nor any agency thereof, nor any of their employees, makes any warranty, express or implied, or assumes any legal liability or responsibility for the accuracy, completeness, or usefulness of any information, apparatus, 'product, or process disclosed, or represents that its use would not infringe privately owned rights. Reference herein to any specific commercial product, process, or service by trade name, trademark, manufacturer, or otherwise, does not necessarily constitute or imply its endorsement, recommendation, or favoring by the United States Government or any agency thereof. The views and opinions of authors expressed herein do not necessarily state or reflect those of the United States Government or any agency thereof.

Reproduced directly from the best available copy.

Available to DOE and DOE contractors from the Office of Scientificand Technical Information, P.O. Box 62, Oak Ridge, TN 37831; prices available from (615) 576-8401.

Available to the public from the National Technical Information Service, U.S. Department of Commerce, 5285 Port Royal Roád, Springfield, VA 22161. 


\section{Floodplain/Wetlands Assessment for the Remediation of Vicinity Property 9 at the Weldon Spring Site, Weldon Spring, Missouri}

by R.A. Van Lonkhuyzen

Environmental Assessment Division,

Argonne National Laboratory, 9700 South Cass Avenue, Argonne, Illinois 60439

November 1995

Work sponsored by United States Department of Energy,

Oak Ridge Operations Office, Oak Ridge, Tennessee 
This report is printed on recycled paper. 


\section{CONTENTS}

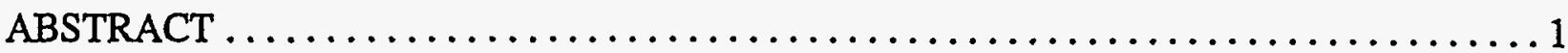

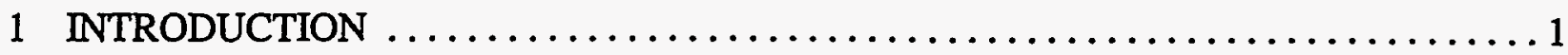

2 DESCRIPTION OF FLOODPLAINS AND WETLANDS OF THE

VICINITY PROPERTY 9 SITE $\ldots \ldots \ldots \ldots \ldots \ldots \ldots \ldots \ldots \ldots \ldots \ldots \ldots \ldots \ldots \ldots$

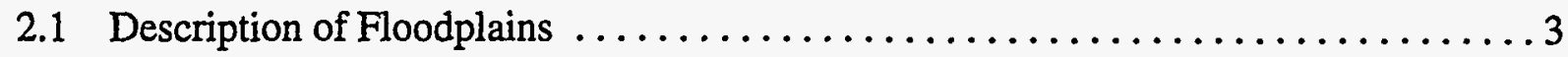

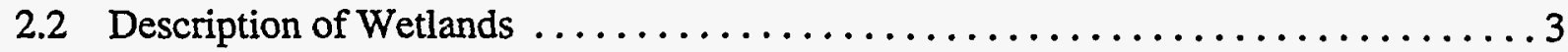

3 IMPACTS TO FLOODPLAINS AND WETLANDS $\ldots \ldots \ldots \ldots \ldots \ldots \ldots \ldots \ldots$

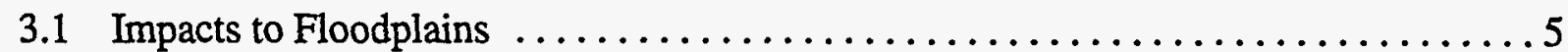

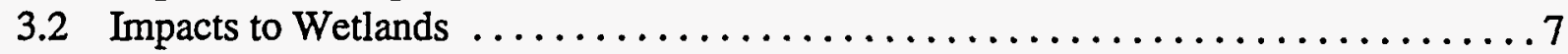

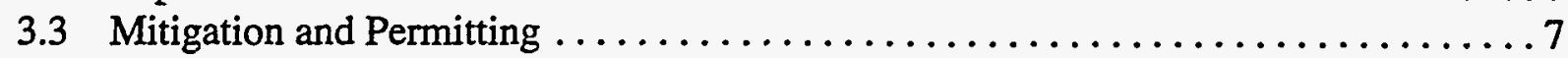

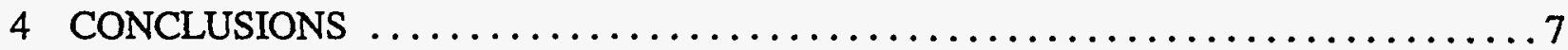

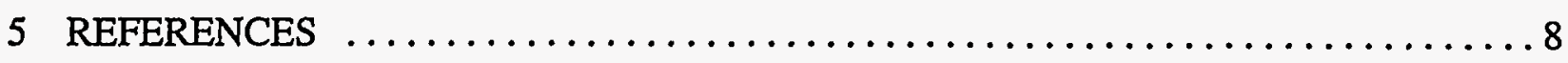

\section{FIGURES}

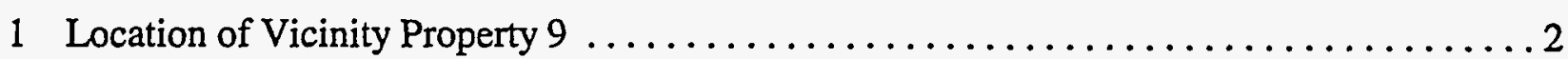

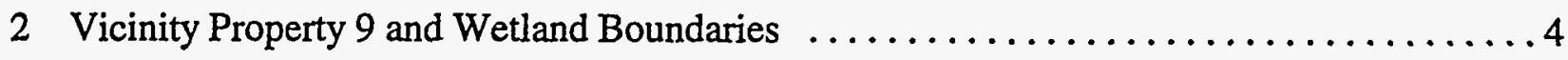

\section{TABLES}

1 Scientific Name, Common Name, and Wetland Indicator of the Dominant Plant Species of the Jurisdictional Wetland

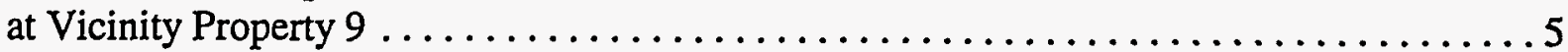

2 Profile Characteristics of Soils within the Jurisdictional Wetland

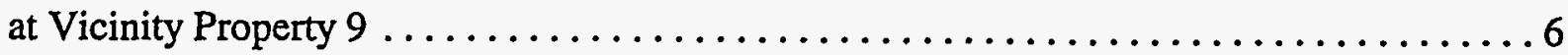





\title{
FLOODPLAIN/WETLANDS ASSESSMENT FOR THE REMEDIATION OF VICINITY PROPERTY 9 AT THE WELDON SPRING SITE, WELDON SPRING, MISSOURI
}

by

R.A. Van Lonkhuyzen

\begin{abstract}
The U.S. Department of Energy (DOE) proposes to excavate contaminated soil at Vicinity Property 9 (VP9), a 0.64-ha (1.6-acre) parcel near the Weldon Spring Site in Missouri. A palustrine wetland approximately 0.10 ha $(0.25$ acre $)$ in size within VP9 would be excavated. Site restoration should allow palustrine wetland to become reestablished. No long-term impacts to floodplains are expected.
\end{abstract}

\section{INTRODUCTION}

The U.S. Department of Energy (DOE) is currently conducting response actions at the Weldon Spring Site under its Environmental Restoration and Waste Management Program. The site, approximately $48 \mathrm{~km}$ [30 mi] west of St Louis, Missouri, is listed on the National Priority List of the U.S. Environmental Protection Agency. Cleanup activities at the Weldon Spring Site will include the remediation of several small scattered sites in the vicinity of the chemical plant and quarry areas.

One of these vicinity properties, VP9, is located approximately $46 \mathrm{~m}$ (150 ft) south of the quarry and immediately north of Femme Osage Slough, within the Weldon Spring Conservation Area (Figure 1). The soils of the property are contaminated with uranium, which is introduced into surface waters when groundwater levels rise above the soil surface.

The DOE is proposing to excavate an area of approximately $116 \mathrm{~m}(380 \mathrm{ft}) \times 55 \mathrm{~m}(180 \mathrm{ft})$ ( 0.64 ha [1.6 acres]), removing surface soils to a depth of approximately $0.3 \mathrm{~m}(1 \mathrm{ft})$, or greater where appropriate. The proposed action is necessary to remove radioactive contamination that poses a potential human health risk.

Several activities would take place prior to excavation: (1) an equipment access ramp would be constructed to provide access to VP9 from the Katy Trail, a gravel roadbed adjacent to VP9 


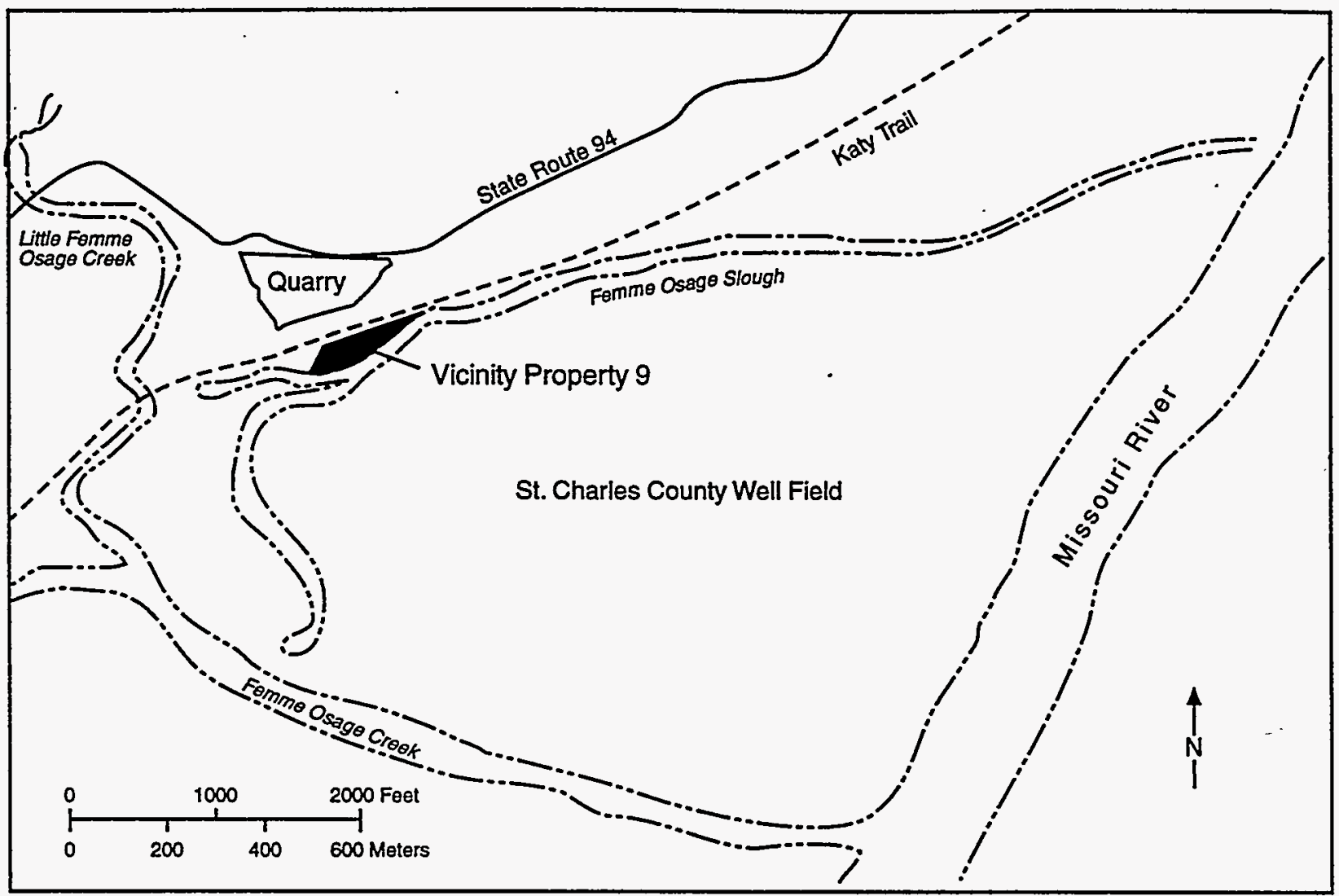

FIGURE 1 Location of Vicinity Property 9

(Figure 1); (2) a portable scanning pad and loading zone would be established:at the site; (3) auger or drill soil sampling would be used to determine the areal extent and depth of contamination and thus the excavation limits; and (4) storm-water runoff controls would be installed around areas to be excavated. Vegetation would then be cleared from VP9, and the contaminated soil removed. The contaminated soil would be transported in closed trucks to the disposal cell located in the chemical plant area. All equipment would be scanned for residual radioactivity before leaving the work area and would be decontaminated as necessary.

Once the contaminated soil was removed, clean borrow fill would be used to replace excavated soil, and the area would be graded to original surface contours. The fill material would consist of upland topsoil previously excavated from the quarry area. The regraded VP9 area would be mulched and seeded with annual grasses, such as winter oats and annual rye, for soil stabilization. Finally, the access ramp and traffic surface would be removed from the haul route, and site restoration completed. The haul route would then be verified as free of radioactive materials. This project is expected to last approximately two months.

This floodplain/wetland assessment evaluates the potential impacts of the excavation to floodplains and wetlands at VP9. The assessment has been prepared in accordance with Executive 
Order 11988, Floodplain Management; Executive Order 11990, Protection of Wetlands; and DOE guidance and policy (Title 10, Code of Federal Regulations, Part 1022 [10 CFR Part 1022]) for compliance with these executive orders.

\section{DESCRIPTION OF FLOODPLAINS AND WETLANDS OF THE VICINITY PROPERTY 9 SITE}

\subsection{DESCRIPTION OF FLOODPLAINS}

The 100-year floodplain of the Missouri River is relatively flat and extends to the base of the escarpment immediately northwest of the Katy Trail (Federal Insurance Administration 1978).

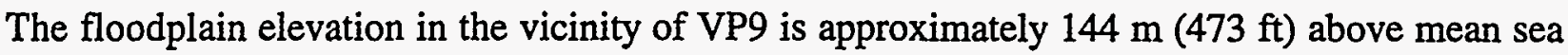
level. Located within the floodplain and to the southeast of VP9 is Femme Osage Slough and the St. Charles County water wellfield. VP9 is located entirely within the 100-year floodplain, with surface

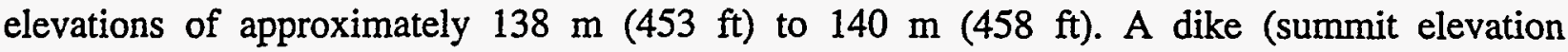

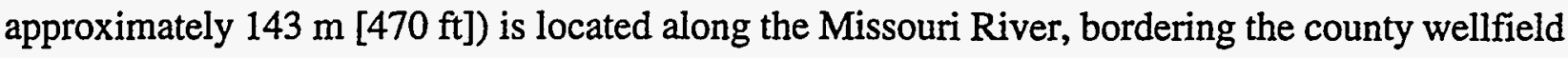
and extending northwest along Femme Osage Creek and Little Femme Osage Creek to the Katy Trail. The dike is designed to reduce the frequency of flooding within the wellfield. Soils of the floodplain in the vicinity of VP9 are Waldron Silty Clay (Tummons 1982), classified as mesic aeric fluvaquents. These soils are somewhat poorly drained, with rare flooding for brief durations.

\subsection{DESCRIPTION OF WETLANDS}

Jurisdictional wetlands in the vicinity of VP9 were delineated on the basis of the 1987 federal guidelines (Environmental Laboratory 1987). To qualify as wetland under these guidelines, an area must have hydrophytic vegetation, wetland hydrology, and hydric soil. Impacts to jurisdictional wetlands are regulated by the U.S. Army Corps of Engineers under Section 404 of the Clean Water Act.

The northeast corner of VP9 contains a small jurisdictional wetland, covering approximately 0.10 ha $(0.25$ acre) (Figure 2$)$. In most years, this area is inundated with shallow surface water for extended periods early in the growing season, but surface water is absent by mid- to late summer. The source of the water is primarily groundwater discharge, with additional contribution from surface-water flow. As groundwater levels rise in the spring, the surface water of the wetland usually becomes continuous with the surface water of the slough. The dominant vegetation within the wetland area consists of hydrophytic species and includes box elder (Acer negundo), silver maple (Acer saccharinum), and green ash (Fraxinus pennsylvanica) in the tree stratum, and clearweed 


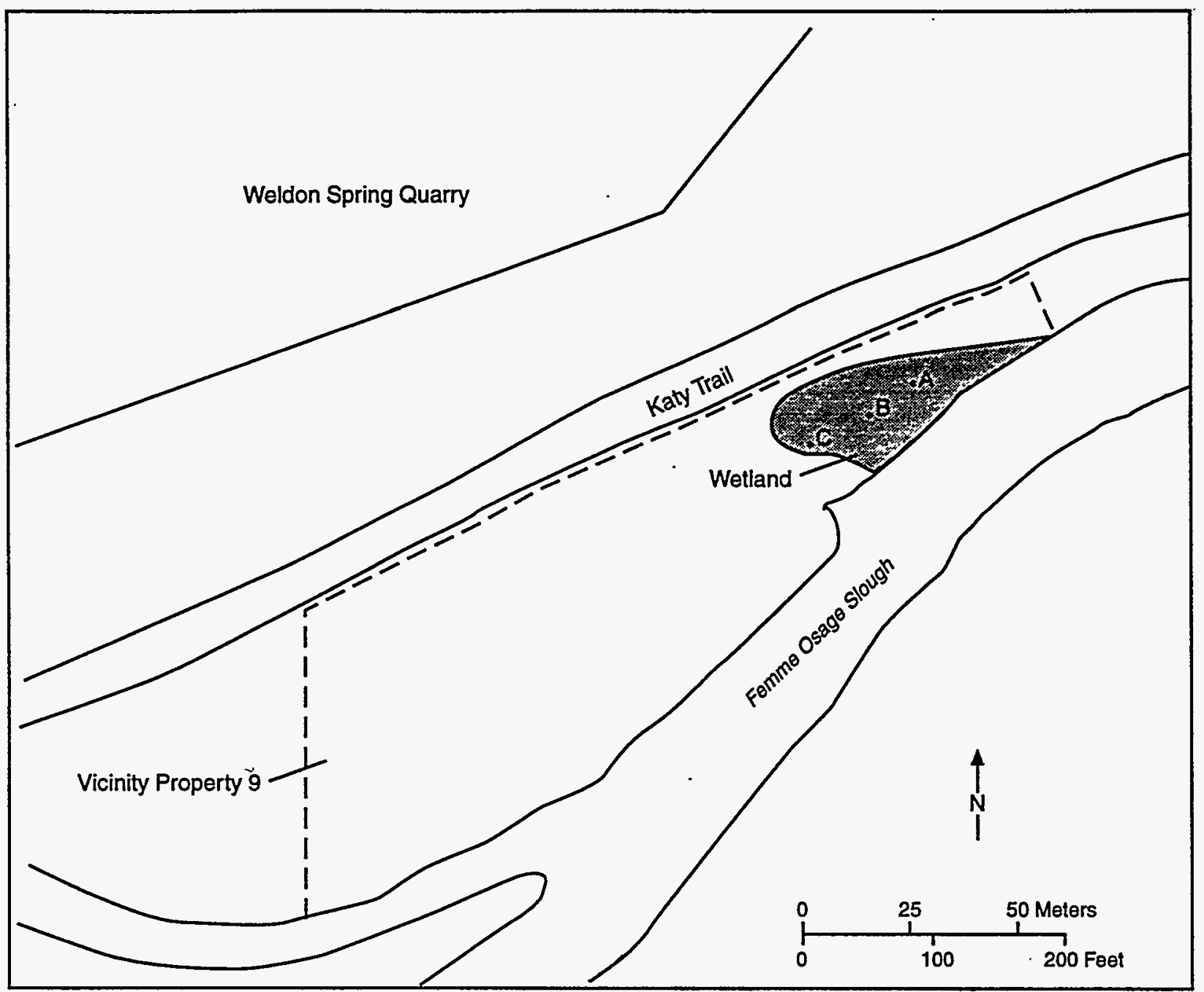

FIGURE 2 Vicinity Property 9 and Wetland Boundaries (Points A, B, and C denote sampling locations)

(Pilea pumila), poison ivy (Toxicodendron radicans), and silver maple seedlings in the herbaceous stratum. The dominant plant species and wetland indicators are presented in Table 1. No state or federally listed threatened, endangered, or rare species have been found, nor are any expected to be found, at VP9. Soils within the wetland are hydric as indicated by the low chroma matrix color. Soil sampling locations are shown in Figure 2, and soil profiles are presented in Table 2. This wetland would be classified as a forested, broad-leaved deciduous, palustrine wetland that is seasonally flooded (Cowardin 1979). Although the ecological impacts of the contamination have not been determined, the presence of the contamination creates the possibility of potential adverse effects on ecosystem structure or function.

The area of Femme Osage Slough near VP9 is not a jurisdictional wetland (it is unvegetated and has steep banks along most of its perimeter) under the current U.S. Army Corps of 
TABLE 1 Scientific Name, Common Name, and Wetland Indicator of the Dominant Plant Species of the Jurisdictional Wetland at Vicinity Property 9

\begin{tabular}{|c|c|c|}
\hline Scientific Name ${ }^{a}$ & Common Name & Wetland Indicator ${ }^{\mathrm{b}}$ \\
\hline Acer saccharinum & Silver maple & FACW \\
\hline Acer negundo & Boxelder & FACW- \\
\hline Fraxinus pennsylvanica & Green ash & FACW \\
\hline Pilea pumila & Clearweed & FACW \\
\hline Toxicodendron radicans & Common poison-ivy & $\mathrm{FAC}+$ \\
\hline \multicolumn{3}{|c|}{ a Nomenclature follows Gleason and Cronquist (1991). } \\
\hline \multicolumn{3}{|c|}{$\begin{array}{l}\text { b Indicators from Reed (1988), FACW = facultative wetland species (67\% } \\
\text { to } 99 \% \text { occurrence in wetlands), FAC = facultative species ( } 34 \% \text { to } 66 \% \\
\text { occurrence in wetlands), }+=\text { the species tends toward the upper end of } \\
\text { the percent range, }-=\text { the species tends toward the lower end of the } \\
\text { percent range (Environmental Laboratory 1987). }\end{array}$} \\
\hline
\end{tabular}

Engineers guidelines (Environmental Laboratory 1987). However, the slough would be classified as "waters of the U.S." and thus is protected under Section 404 of the Clean Water Act. Femme Osage Slough is identified by the National Wetlands Inventory (U.S. Fish and Wildlife Service 1989b) as an unconsolidated bottom, lower perennial riverine wetland that is permanently flooded. The area between Femme Osage Slough and the Katy Trail, including VP9, also is identified by the National Wetlands Inventory (U.S. Federal Wildlife Service 1989a) as a forested, broad-leaved deciduous, palustrine wetland that is temporarily flooded. However, this area, except for the wetland discussed above, does not exhibit indicators of wetland hydrology or hydric soils and therefore would not be considered a jurisdictional wetland.

\section{IMPACTS TO FLOODPLAINS AND WETLANDS}

\subsection{IMPACTS TO FLOODPLAINS}

No long-term impacts to the 100-year floodplain of the Missouri River would be expected under the proposed action, although the floodplain would be temporarily disturbed during cleanup. To prevent disturbance and migration of contaminants to areas outside of VP9, sediment and erosion controls such as silt fencing and hay bales would be used. No permanent structures would be 
TABLE 2 Profile Characteristics of Soils within the Jurisdictional Wetland at Vicinity Property 9

\begin{tabular}{|c|c|c|c|}
\hline Point $^{a}$ & Depth $(\mathrm{cm})$ & Matrix $^{b}$ & Mottles \\
\hline \multirow[t]{6}{*}{ A } & $0-10.2$ & $10 \mathrm{YR} 3 / 1.5$ & None \\
\hline & $10.2-15.2$ & 10YR4/0.5 & None \\
\hline & $15.2-25.4$ & $10 \mathrm{YR} 5 / 2$ & 10YR4.5/1 (25\%) \\
\hline & & & 10YR4.3 (5\%) \\
\hline & $25.4-35.6$ & $10 \mathrm{YR} 4 / 2.5$ & 10YR4.5/1 (40\%) \\
\hline & & & 10YR4/3 (10\%) \\
\hline \multirow[t]{6}{*}{ B } & $0-10.2$ & $10 \mathrm{YR} 3 / 2$ & 10YR4/4 (5\%) \\
\hline & $10.2-15.2$ & 10YR4/1 & $10 \mathrm{YR} 3 / 2(10 \%)$ \\
\hline & $15.2-20.3$ & $10 \mathrm{YR} 4.5 / 2$ & $10 Y R 4.5 / 3(10 \%)$ \\
\hline & & & 10YR4/1 (10\%) \\
\hline & $20.3-35.6$ & 10YR4.5/2 & 10YR4.5/3 (25\%) \\
\hline & & & 10YR4.5/1 (25\%) \\
\hline \multirow[t]{3}{*}{$\mathrm{C}$} & $0-10.2$ & 10YR3/1.5 & None \\
\hline & $10.2-14.0$ & 10YR3/1 & 10YR3/1.5 (20\%) \\
\hline & $14.0-35.6$ & $10 \mathrm{YR} 4 / 2$ & 10YR3/1 (30\%) \\
\hline
\end{tabular}

a Sampling points are shown in Figure 2.

b Soil colors from Munsell Soil Color Chart (Kollmorgen Corp. 1990). Soil color designations (e.g. 10YR3/2) include hue(10YR), value(3), and chroma(2).

constructed within the floodplain, and final soil surface contours would be similar to the original topography. Thus, no change in flood storage capacity would occur.

If the proposed action is not undertaken (i.e., no action), no impacts would be expected to the flood storage capacity of the Missouri River 100-year floodplain. However, radioactive materials would continue to contaminate the soils and surface waters of the floodplain, with the potential for adverse ecological and human health effects. 


\subsection{IMPACTS TO WETLANDS}

The vegetation and surface soils, along with soil fauna, of the wetland within VP9 would be removed under the proposed action. Although wetland characteristics and functions would be temporarily disrupted, similar wetland could be reestablished. Upon completion of the project, final soil surface contours would have been restored to the original topography. Hydrologic characteristics would be similar to those originally present at VP9, allowing the area to retain surface drainage patterns and remain a site of groundwater discharge. Hydrophytic vegetation should become reestablished under the anaerobic soil conditions that would result. Initially, upland species would be planted for soil stabilization, but hydrophytic species, which occur in adjacent floodplain areas, would be expected to colonize the wetland. Although the composition of the wetland vegetation community would be difficult to predict and would change over time, species likely to colonize would include silver maple, cottonwood (Populus deltoides), smartweed (Polygonum pensylvanicum), and beggar-ticks (Bidens spp.). Although disturbance to the wetland would not occur if no action were taken, radioactive materials would continue to contaminate the soils and surface waters of the wetland, and a potential for ecological effects due to the contamination would continue.

\subsection{MTIGATION AND PERMITTING}

A storm-water control plan would be implemented to prevent sedimentation and erosion impacts to adjacent floodplain areas and surface waters. All equipment and road surfaces would be decontaminated as necessary upon completion of project activities. The excavation of the 0.10 -ha (0.25-acre) wetland within VP9 has been authorized by the U.S. Army Corps of Engineers under Nationwide Permit No. 38 (Brazier 1995). Minimization of wetland impacts, as described in Section 4.2.1, in compliance with 10 CFR Part 1022, would be accomplished by successful redevelopment of the excavated wetland. In addition, monitoring of wetland development should be conducted on a periodic basis to ensure the success of wetland reestablishment.

\section{CONCLUSIONS}

No long-term impacts to the Missouri River floodplain are expected from the proposed action. The temporary disturbance due to excavation activities would cease following restoration of the site. A wetland approximately $0.10 \mathrm{ha}(0.25 \mathrm{acre})$ in size would be excavated, with soil removed

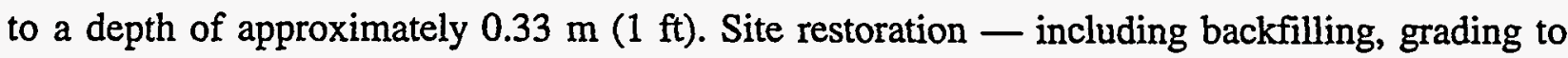
original contours, and revegetating - should allow wetland functions to become reestablished. 


\section{REFERENCES}

Brazier, M.A., 1995, letter from Brazier (Chief, Regulatory Branch, St. Louis District, U.S. Army Corps of Engineers, St. Louis, Mo.) to S.H. McCracken (Project Manager, Weldon Spring Site Remedial Action Office, Weldon Spring, Mo.), June 12.

Cowardin, L.M., et al, 1979, Classification of Wetlands and Deepwater Habitats of the United States, FWS/OBS-79/31, U.S. Fish and Wildlife Service, Washington, D.C.

Environmental Laboratory, 1987, Corps of Engineers Wetlands Delineation Manual, Technical Report Y-87-1, U.S. Army Engineer Waterways Experiment Station, Vicksburg, Miss.

Federal Insurance Administration, 1978, "Flood Insurance Rate Map, St. Charles County, Missouri (Unincorporated Areas)," community-panel number 2903150325 A, U.S. Department of Housing and Urban Development, National Flood Insurance Program, p. 325.

Gleason, H.A., and A. Cronquist, 1991, Manual of Vascular Plants of Northeastern United States and Adjacent Canada, Second Edition, The New York Botanical Garden, Bronx, New York.

Kollmorgen Corporation, 1990, Munsell Soil Color Charts, Macbeth Division of Kollmorgen Corporation, Baltimore, Md.

Reed, P.B., Jr., 1988, National List of Plant Species that Occur in Wetlands: North Central (Region 3), U.S. Fish and Wildlife Service Biological Report 88 (26.3).

Tummons, R.L., 1982, Soil Survey of St. Charles County, Missouri, U.S. Soil Conservation Service, Washington, D.C.

U.S. Fish and Wildlife Service, 1989a, "National Wetlands Inventory Map, Defiance, MO, Quadrangle," U.S. Department of the Interior, National Wetlands Inventory, St. Petersburg, Fla.

U.S. Fish and Wildlife Service, 1989b, "National Wetlands Inventory Map, Weldon Spring, MO, Quadrangle," U.S. Department of the Interior, National Wetlands Inventory, St. Petersburg, Fla. 